\title{
Produk Layanan Transaksi Online Studi Pada PT Bank Syariah Mandiri Menurut Perspektif Ekonomi Syariah
}

\author{
Muhammad Alimuddin ${ }^{1 *}$,Nurdin Nurdin ${ }^{2}$, Rizki Amalia ${ }^{3}$ \\ ${ }^{1}$ Jurusan Perbankan, Fakultas Ekonomi dan Bisnis Islam, IAIN Palu \\ ${ }^{2}$ Jurusan Perbankan, Fakultas Ekonomi dan Bisnis Islam, IAIN Palu \\ ${ }^{3}$ Jurusan Perbankan, Fakultas Ekonomi dan Bisnis Islam, IAIN Palu
}

ABSTRAK

Tulisan ini membahas produk layanan transaksi online studi pada PT bank syariah mandiri menurut perspektif ekonomi syariah. Penelitian ini bersifat pendekatan kualitatif, dengan menggunakan teknik dalam pengumpulan data melalui observasi, wawancara dan dokumentasi. Sedangkan sumber data yang di peroleh dari pimpinan cabang dengan penyajian data, reduksi data dan verfikasi data. Hasil penelitian menunjukkan bahwa produk layanan transaksi online (mobile banking) direspon baik oleh nasabah atau pengguna mobile banking karena layanan yang bersifat mempermudah nasabah dalam melakukan transaksi secara online. Disamping itu produk layanan transaksi online banking diberikan BSM kepada nasabah juga agar nasabah bebas melakukan transaksi dimana saja dan kapan saja yang tidak terikat oleh waktu dan tempat. Saran penelitian adalah BSM perlu meningkatkan transaksi secara online yang lebih canggih dan maju untuk kemudahan para pelaku bisnis dan usaha di bidang teknologi dan informasi dalam melakukan transaksi untuk mendapatkan kemaslahatan bagi umut manusia secara umum khususnya di dunia perbankan syariah.
INFORMASI

ARTIKEL

Katakunci:

Online Banking, Transaksi, Bank Syariah Mandiri, Ekonomi Syariah 


\section{PENDAHULUAN}

Dalam kegiatan ekonomi merupakan suatu hal yang tidak bisa terpisahkan dengan tindakan manusia dalam rangka pemenuhan kebutuhannya untuk bertahan hidup. Oleh karena itu kegiatan ekonomi merupakan hal yang sangat urgent dalam dinamika kehidupannya. Seiring berjalannya waktu kebutuhan manusia semakin berkembang yang menjadikan kegiatan ekonomi semakin variatif. Bersamaan dengan itu bermunculan lembaga penunjang kemajuan ekonomi, salah satunya adalah lembaga perbankan yang mengatur alur kas keuangan. Perkembangan keuangan di dunia barat dalam bentuk pelembagaan tumbuh subur dengan sentuhan teknologi yang memudahkan arus transakasi.

Satu hal yang menjadi ciri khas dari keuangan ini khususnya pada perbankan adalah penggunaan bunga pada sistem operasionalnya.Kehadiran perbankan dalam dunia Islam bukan hal yang asing lagi, karna institusi perbankan sudah dikenal sejak masa pertengahan Islam dahulu. ${ }^{1} \quad$ Sejarah perekonomian umat Islam pembiayaan yang dilakukan dengan akad yang sesuai syariah telah menjadi bagian dari tradisi umat Islam sejak zaman Rasulullah saw.

${ }^{1}$ Riza Yulista Fajar, "Riba dan Bunga Bank dalamPandanganMuhammadSyafi 'iAntonio,",(Yogya karta:FakultasSyari'ahUINSunanKalijaga,2009),2.
Praktik praktik seperti menerima titipan harta, meminjamkan uang untuk keperluan konsumsi dan keperluan bisnis, serta melakukan pengiriman uang, telah lumrah dilakukan sejak zaman Rasulullah saw. Dengan demikian fungsi fungsi utama perbankan modern yaitu menerima deposit, menyalurkan dana, dan melakukan transfer dan telah menjadi bagian yang tidak terpisahkan dari kehidupan umat Islam sejak zaman Rasulullah saw. ${ }^{2}$ Penggunaan cek juga telah dikenal luas sejalan dengan meningkatnya perdagangan antara negeri Syam dengan yaman, yang paling tidak berlangsung dua kali dalam setahun. Bahkan pada masa pemerintahan Khalifah Umar bin Khatab r.a. menggunakan cek untuk membayar tunjangan pada mereka yang berhak. Dengan menggunakan cek ini mereka dapat mengambil gandum di Baitul Mal yang ketika itu di impor dari mesir.

Perkembangan teknologi dalam bidang bisnis tidak mesti bertemu atau tatap muka secara langsung melainkan lewat medium internet (transaksi online), sehingga transaksi online ini tidak asing lagi di negara maju atau berkembang seperti Indonesia ${ }^{3}$.

\footnotetext{
${ }^{2}$ Adiwarman, A Karim, Bank Islam Analisis Fiqih dan Keuangan(Depok: PT RajaGrafindo Persada. 2017), 18-19

${ }^{3}$ Nurdin, N. (2016). The Roles of Information Technology in Islamic Bank Knowledge Management: A study of Two Syariah Banks in Palu. Hunafa: Jurnal Studia Islamika, 13(2), 181-217. doi: https://doi.org/10.24239/jsi.v13i2.444.181-217
} 
Seiring berjalanya waktu transaksi online pun lebih berkembang dilakukan dalam akad-akad bank syariah untuk mempermudah dan mempercepat proses bisnis terutama di bidang jual beli barang dan jasa yang sifatnya jarak jauh.

Dengan adanya transaksi online tentu diikuti dengan dengan perkembangan tekhnologi informasi dan telekomunikasi. Teknologi tidak dapat di pisahkan dari kehidupan manusia zaman modern ini, karna teknologi sudah banyak membantu masyarakat, industri, hingga pemerintah untuk mendapatkan informsi dengan cepat dan mudah. Bank syariah melihat pemanfaatan teknologi memberikan efektifitas dalam memberikan pelayanan, aspek keamanaan, dan kemudahan pengguna kepada nasabah. Peningkatan kualitas pelayanan jasa yang dilakukan bank syariah yaitu dengan mobile banking.

Mobile banking merupakan layanan jasa yang menggunakan teknologi informasi. Mobile banking atau bisa disebut M-Banking merupakan suatu layanan perbankan yang diberikan pihak bank untuk mendukung kelancaran dan kemudahan pengguna dalam kegiatan perbankan. Pengguna mobile bangkingtidak perlu lagi bank ataupun ke ATM untuk mengecek saldo, transfer, dan membayar listrik air hingga membayar zakat.Mobile bankingmembutuhkan media berupa telepon seluler. Fitur Mobile bankingdapat di akses di dengan cara mengunduh aplikasi layanan mobile banking di aplikasi store yang disediakan pada smartphone yang dimiliki oleh nasabah.

Dengan demikian berkat adanya fsilitas mobile banking seperti yang dijelaskan sebelumnya, orang-orang sibuk bekerja dan tidak memiliki banyak waktu untuk pergi ke bank, saat ini dapat dengan mudah melakukan transaksi finansialnya dimana saja dan kapan saja selama terhubung dengan internet. Oleh karena itu, penulis merasa tertarik untuk melakukan penelitian yang berkaitan dengan transaksi mobole banking menurut perspektif ekonomi syariah. $^{4}$

\section{TINJAUAN PUSTAKA}

\subsection{Mobile Banking}

Mobile banking adalah salah satu jasa layanan perbankan yang di akses langsung melalui jaringan telepon seluler atau handphone GSM (Global For Mobile Communication) atau CDMA dengan menggunakan layanan data atau yang telah disediakan oleh operator seluler misal XL, Indosat, Telkomsel, dan operator lainya. ${ }^{5}$

${ }^{4}$ Reza Ramadhan, "Persepsi Kemudahan Penggunaan, Kredibiliitas, dan Persepsi Harga Pada Niat Nasabah Menggunakan Layanan Mobile Banking di Bank Syariah Mandiri Surabaya”, (Surabaya: Fakultas Ekonomi dan Bisnis Islam, Universitas Air Langga, 2016) 3.

${ }^{5}$ Maryanto Supriyono, Buku Pintar Perbankan, (Yogyakarta:2011), 67. 
Mobile banking merupakan jenis jasa layanan untuk melayani transaksi non-tunai, seperti proses transfer. Apabila menggunakan layanan mobile banking, proses transfer dapat dilakukan kapan saja dan dimana saja tidak tergantung pada jam operasional bank. ${ }^{6}$ Mobile banking atau yang dikenal dengan sebutan M-Banking merupakan sebuah fasilitas atau layanan perbankan menggunakan alat komunikasi bergerak seperti handphone, dengan penyediaan fasilitas untuk bertransaksi perbankan melalui aplikasi pada handphone. Dengan adanya layanan handphone dan layanan Mobile banking, transaksi perbankan yang biasanya dilakukan secara manual, artinya kegiatan yang sebelumnya dilakukan nasabah dengan mendatangi bank, kini dapat dilakukan tanpa harus mengunjungi bank, hanya dengan menggunakan handphone nasabah dapat menghemat waktu dan biaya. Layanan mobile bankingmemberikan kemudahan kepada para nasabah untuk melakukan transaksi perbankan seperti cek salso, tranfer antar rekening, pembayaran tagihan dan isi pulsa.

Dari kemudahan yang didapatkan dari layanan mobile banking terdapat juga kelemahan seperti, terbatasnya pengelolaan transaksi keuangan sehingga tidak bisa

\footnotetext{
${ }^{6}$ Mohammad Irianto, Prosedur Audit Operasional Bank:Audit Terapan Berbasis Resiko, (Bandung: Ikhlas Media, 2014), 55.
}

membuat transaksi keuangan yang banyak dalam satu waktu sekaligus, selain itu biaya yang dikenakan untuk mobile banking lebih mahal dan terkadang ada tambahan biaya administrasi lainya untuk transaksi-transaksi tertentu, pengenaan tarif biasanya Rp 500; pengiriman pemberitahuan transaksi yang terlambat diterima oleh nasabah. Dalam proses transaksi layanan ini harus terkoneksi dengan jaringan Internet. ${ }^{7}$

Mobile banking secara umum saat ini dapat digolongkan menjadi 3 golongan yaitu: 1. Informational (bersifat memberi informasi)

Didalam sistem ini, hanya memuat informasi mengenai produk-produk dan layanan-layanan yang dimiliki oleh suatu bank. Resiko dari sistem ini tergolong cukup rendah, karena sistem ini sama sekali tidak terhubung dengan server utama dan jaringan yang ada di Bank, tetapi hanya terhubung dengan server hosting situs. Resiko yang mungkin akan terjadi adalah pengubahan isi dari situs di internet atau sering dikenal dengan istilah deficel. Hal ini tidak membahayakan keseluruhan sistem dari bank tersebut, tetapi akan dapat mengacaukan informasi yang ada di situs bank yang bersangkutan.

2. Communicative (bersifat komunikatif)

\footnotetext{
${ }^{7}$ Kelebihan dan Kekurangan Internet Banking dan Sms Banking, diakses dari http;//www.paketwisatatour. net 2015 pada tanggal 13 Maret 2019.
} 
Tipe yang kedua ini lebih bersifat interaktif dibandingkan dengan tipe yang pertama. Pada tipe sistem ini, dimungkinkan terjadinya interaksi antara konsumen (nasabah) dengan sistem yang ada di bank. Interaksi itu dapat berupa informasi saldo, laporan transaksi, pengubahan data pribadi nasabah, maupun formulir-formulir keanggotaan layanan dari bank yang bersangkutan $^{8}$. Dilihat dari cara kerjanya, resiko dari sistem ini jelas lebih besar dibandingkan dengan yang pertama. Hal ini dikarenakan adanya hubungan antara nasabah dengan beberapa server di jaringan di bank, untuk diperlukan pengawasan dan pencjagaan lebih di sistem ini, untuk mencegah penyusup maupun programprogram yang dapat merusak sistem seperti virus, trojan, dan lain-lain.

\section{Transactional (dapat melakukan} transaksi)

Tipe yang terakhir merupakan tipe yang ada di bank, maka resiko yang dimiliki sistem ini juga cukup besar, paling besar dibandingkan dengan du tipe sebelumnya. Oleh sebab itu, kontrol yang ketat diperlukan didalam sistem ini. Transaksi yang dapat dilakukan di sistem ini dapat meliputi akses langsung ke account di bank. seperti informasi saldo ataupun transaksi trakhir, pembayaran tagihan, transfer dana, isi ulang pulsa, dan lain-lain. ${ }^{9}$

\subsection{Perkembangan Transaksi Mobile}

\section{Banking}

Mobile banking merupakan salah dsatu bagian dari layanan melaluiElectronic Banking yang selalu mengalami perkembangan. Perkembangan ini dipengaruhi oleh beberapa bidang teknologi, yaitu:

kepada perkembangan teknologi mikroprosesor (sebagai otak dari komputer). yang paling lengkap dibandingkan dengan 2. Sofware, kemampuan suatu aplikasi program tipe-tipe yang lain, dan pada umumnya juga memuat sistem pada dua tipe sebelumnya. selalu berkembang dan banyak sekali sofware yang dikembangkan untuk manusia. Pada sistem di tipe yang ketiga ini, nasabah 3. Teknologi Komunikasi Data. Dalam dimungkinkan untuk melakukan transaksi secara langsung. Karena sistem ini memiliki jalur langsung ke server utama dan jaringan

\footnotetext{
${ }^{8}$ Nurdin, N. (2019). Knowledge Integration Strategy in Islamic Banks. In A. Helena \& S. Bernardete (Eds.), The Role of Knowledge Transfer in Open Innovation (pp. 118-138). Hershey, PA, USA: IGI Global.
} teknologi telekomunikasi dibagi menjadi dua macam yaitu, Voice dan data. Dan sekarang banyak sudah perubahan teknologi lainnya untuk para penggunanya.

\footnotetext{
${ }^{9}$ Novita Putri Wulandari, Analisis FaktorFaktor Penggunaan Mobile Banking di Bandung, Bisnis dan Iptek Vol.10, No.2, Oktober 2017, 139.
} 
4. Host to Host. Hubungan yang berkaitan dengan kerja sama antara pihak bank dengan pihak lainnya.

\subsection{Keamanan Transaksi Mobile}

\section{Banking}

Dalam menggunakan mobile banking tentu saja setiap bank memberikan keamanan saat bertransaksi.

Secara umum beberapa keamanan dalam bertransaksi mobile banking yakni:

1. PIN merupakan kode akses sehingga no PIN merupakan kode rahasia pribadi, tidak boleh orang lain mengetahuinya.

2. User ID bersifat rahasia untuk setiap nasabah dan keytoken tidak di pinjamkan ke orang lain.

3. Penggantin PIN secara berkala juga menjadi cara yang baik untuk menjaga keamanan dan meminimalkan resiko.

4. SIM card handphone juga harus dilindungi karena biasanya nomor telepon sudah terdaftar di database komputer bank untuk dapat berintraksi melalui phone banking.

5. Nasabah juga harus berhati-hati, karena banyaknya orang-orang jahat yang mencoba memanfaatkan kelegahan nasabah baik melalui phising atau hacker.

\subsection{Keuntungan mobile banking}

Dalam menggunakan transaksi ini dapat keuntungan tersendiri antara lain:
1. Dapat bertransaksi dimana saja dan kapan saja tanpa tanpa harus mengantri di ATM.

2. Sangat efesien, transaksi dapat dilakukan dengan menggunakan handphone, sehingga waktu lebih efesien.

3. Aman, mobile banking dilengkapi dengan security ID dan PIN untuk menjamin keamanan dalam penggunaannya.

\section{$2.4 \quad$ Resiko Mobile Banking}

Resiko yang banyak terjadi adalah adanya orang atau sekelompok orang yang dengan sengaja melakukan kegiatan phising. Artinya mereka membuat situs yang mirip dengan situs bank aslinya, sehingga tanpa disadari oleh nasabah yang bersangkutan sedang mengakses situs palsu karena logo bank dan formatnya sama persis menyerupai aslinya. $^{10}$

\section{METHODOLOGY}

Dalam penulisan karya ilmiah ini, penulis menggunakan metode pendekatan penelitian deskripsi kualitatif, yaitu memaparkan aspek-aspek yang menjadi sasaran penelitian penulis. Pendekatan yang dimaksud yaitu suatu penelitian yang berusaha untuk menuturkan pemecahan masalah yang ada sekarang berdasarkan data-data, sehingga penulis dapat menemukan kepastian dan keaslian data

\footnotetext{
${ }^{10} \mathrm{Ibid}$, hlm 67-69.
} 
untuk diuraikan sebagai hasil penelitian yang akurat. Penelitian yang bersifat deskriptif menurut Suharsimi Arikunto "lebih tetap apabila menggunakan pendekatan kualitatif'. ${ }^{11}$

Adapun yang menjadi objek atau sasaran lokasi penelitian adalah PT. Bank Syariah Mandiri (BSM) Kantor Cabang Palu, Jl. Wolter Monginsidi Nomor.77 Palu. Ini menunjukan bawah lokasi penelitian di anggap sangat representatif terhadap judul penelitian yang diangkat penulis, karena disamping objek dianggap tepat, juga memberikan nuansa baru bagi penelitian dalam menambang pengalaman penelitian, khususnya pada Bank Syariah Mandiri Palu.

Data dikumpul melalui observasi, wawancara mendalam, dan dari berbagai dokumen yang ada. Dalam wawancara peneliti melakukan wawancara langsung dengan informan di Bank Syariah Mandiri Palu yang dapat memberikan data yang menyakut masalah atau objek peneliti dalam bahasa ini yang diwawancarai adalah pimpinan BSM dan nasabah yang menggunakan produk online banking. Nasabah yang diwawancarai ada lima orang nasabah yang menggunakan online banking dalam bertransaksi dengan BSM.

Data dianalisa dengan pendekatan reduksi, penyajian, dan verifikasi dengan

${ }^{11}$ Suharsimi Arikunto, Prosedur Penelitian Ilmiah, Suatu Pendekatan Praktek,Ed. II, (Cet. IX ; Jakarta : Rineka Cipta, 1993)h 209; berbagai data yang berasal dari seumber berbeda. Tujuannya yaitu untuk memastikan ke-validitan data yang diperoleh.

\section{HASIL DAN PEMBAHASAN}

\subsection{Penerapan Mobile Banking Pada PT}

Bank Syariah Mandiri.

Lembaga keuangan memberikan layanannya tidak saja melalui model-model konvensional, namun saat ini sudah beralih ada pemanfaatan teknologi informasi. Kondisi ini dipacu oleh perkembangan ilmu pengetahuan dan teknologi informasi. Dahulu lembaga keuangan bank dalam memberikan layanannya lebih menekan kepada model face to face, namun sejak teknologi informasi mampu mendukung terhadap sistem transaksi lembaga keuangan bank, sehingga seiring berjalannya waktu dengan hadirnya teknologi sehingga saat ini model transaksi lebih mengedepankan Pada model non face to face digital documen.

Berikut ini hasil pemaparan atau penjelasan penulis melalui wawancara dengan pimpinan cabang PT Bank Syariah Mandiri Palu selaku informan mengenai penerapan mobile banking di PT Bank Syariah Mandiri Palu. Adapun hasil wawancara penulis dengan pak Andi Muhammad Amrin yang mengatakan bahwa: "sebelum mengetahui penerapan mobile banking secara jauh terlebih dahulu kami mendefinisikan apa itu mobile banking ?. Nah mobile berarti bergerak atau sebagai perantara, 
artinya sebuah fasilitas layanan dalam memberikan kemudahan akses atau kecepatan dalam memperoleh informasi terkini dan transaksi finansial secara real time". ${ }^{12}$

Mobile banking dapat di akses oleh nasabah perorangan melalui ponsel yang memiliki tekhnologi GPRS. Produk layanan mobile banking adalah salah saluran distribusi bank untuk mangakses rekening yang dimiliki oleh nasabah melalui teknologi GPRS dengan sarana telepon seluler (ponsel). Perkembangan teknologi informasi yang sedemikian pesat sangat mendukung dalam kecepatan dan kemudahan layanan transaksi perbankan terhadap nasabah. Untuk mengantisipsi hal tersebut, perbankan berupaya untuk mengembangkan teknologi mobile banking yang dimiliki saat ini.

GPRS (General Package Radio Service) adalah teknologi penyampaian data melalui ponsel, teknologi ini lebih maju dibandingkan dengan teknologi SMS seperti sms banking meskipun boleh dikatakan sms banking anak payung dari mobile banking dan untuk saat ini sms banking perlahan tidak atau jarang dipakai dalam bertransaksi online disebabkan aplikasi sms banking memiliki keterbatasan dalam mengakses. Teknologi GPRS ini juga memiliki beberapa kelebihan dibandingkan dengan teknologi SMS diantaranya yaitu: dapat digunakan sebagai media untuk mengirim perintah

\footnotetext{
${ }^{12}$ Andi Muhammad Amrin, Wawancara, Palu 06 November 2019.
}

transaksi perbankan dan data yang dikirim ke bank dapat melalui proses pengkodean terlebih dahulu.

Dalam layanan aplikasi mobile banking tentu mempunyai suatu kelebihan yang dimana bertujuan untuk mempermudah para pengguna untuk melakukan sebuah transaksi secara online, sehingga para pengguna mobile banking tidak perlu lagi ke bank untuk melakukan transaksi. Pada aplikasi mobile banking cukup klik aplikasi mobile banking akan muncul fitur-fitur layanan sehingga nasabah atau pengguna mobile banking yang tinggal dipilih layanan mana yang akan digunakan untuk melakukan transaksi. Dalam penggunaan layanan tersebut tentu saldo yang ada didalam rekening akan berkurang karena adanya suatu pembelian pada fitur yang sudah diplih.

Berikut ini hasil pemaparan atau penjelasan penulis melalui wawancara dengan pimpinan cabang PT Bank Syariah Mandiri Palu selaku informan mengenai manfaat mobile banking di PT Bank Syariah Mandiri Palu. Adapun hasil wawancara penulis dengan pak Andi Muhammad Amrin yang mengatakan bahwa:

\footnotetext{
"Aplikasi mobile bankingtidak hanya dikembangkan oleh bank syariah mandiri saja akan tetapi semua bank mengembangkannya. Kegunaan mobile banking yaitu untuk lebih mengembangkan layanan perbankan
} 
secara modern, kalau masa dulu layanan perbankan masih bersifat terbatas Cuma transaksi tarik tunai, setor tunai dan transfer itupun harus dilakukan di bank, seiring dengan perkembangan tekhnologi kemudian layanan perbankan ini di perluas karena transaksi yang dilayani juga semakin banyak. Dengan adanya aplikasi mobile banking nasabah atau pengguna mobile banking misalkan ingin membeli pulsa, token listrik, bayar tagihan, top up e-Money dan zakat infaq bisa dengan menggunakan rekening bank tanpa harus ke bank cukup lewat telepon seluler saja. Akan tetapi selain keperluan tarik tunai dan setor tunai seperti layanan tambahan bisa dilakukan dimna saja dan kapan saja tanpa dibatasi oleh tempat dan waktu". ${ }^{3}$

Adapun manfaat mobile banking yaitu:

a. Kenyamanan bertransaksi kapan saja dan dimana saja.

b. Kemudahan melakukan transaksi seperti layaknya di ATM

c. Dapat diaplikasikan pada semua jenis SIM Card dan ponsel yang menggunakan tekhnologi GPRS.

d. Dilengkapi fitur spesial tranfer real time ke bank dan transfer ke bukan pemegang rekening.

Dalam menggunakan aplikasi mobile banking nasabah akan menemukan beberapa fitur yang ada di aplikasi tersebut seperti beli pulsa, token listrik, dan lain-lain yang bisa digunakan dalam bertransaksi, sehingga dampakmobile bankingkepada nasabah yaitudapat memenuhi kebutuhan nasabah maka secara otomatis akan loyal kepada

\footnotetext{
${ }^{13}$ Andi Muhammad Amrin, Wawancara, Palu 06 November 2019.
}

apikasi mobile banking atau fitur-fitur yang ada di dalamnya lebih-lebih kepada institusi atau bank yang mengembangkan aplikasi dan fitur tersebut. Namun sebaliknya apabila aplikasi mobile banking mempunyai problem atau kelemahan dalam sistem jaringan biasanya, ketika di aplikasikan oleh nasabah maka disitu pihak bank secara teliti memeriksa dan memulihkan lagi aplikasinya supaya loyalitas nasabah pada mobile bankig tetap terjaga dan atas nama baik institusi yang sudah mengembangkan aplikasi tersebut.

Dengan melihat dampak yang akan terjadi pada aplkasi mobile banking maka tentu pihak bank mempunyai sistem yang yang digunakan dalam aplikasi tersebut sesuai dengan hasil wawancara dengan bapak Andi Muhammad Amrin yang mengatakan bahwa:

"Pertama, Memanfaatkan teknologi yang ada, kedua, Karena berkaitan dengan dana atau keuangan nasabah maka harus dilengkapi dengan jaminan keamanan bertransaksi, sehingga dengan kemajuan teknologi bank mempunyai kesempatan untuk mengembangkan teknologi tersebut. Akan tetapi dalam hal ini juga mempunyai resiko maka harus ada jaminan keamanan. Nah apa saja jaminan yang disiapkan oleh bank yaitu PIN (Personal identification Number), Kode-kode tertentu yang dimasukkan, tujuannya adalah untuk mencegah supaya aplikasi mobile banking tersebut tidak mudah diretas atau di bobol yang berkaitan dengan segala sesuatu yang merugikan 
nasabah sesuai dengan kebijakan bank yang berlaku". ${ }^{14}$

Dengan adanya teknologi tentu Bank Syariah Mandiri akan memanfaatkan teknolgi tersebut dengan mengembangkan aplikasi online berupa mobile banking. Bank sebagai lembaga jasa untuk para nasabah tentu tidak akan lalai dalam menjaga situs yang dapat mempermudah dan mempercepat bahkan mengefesienkan waktu para nasabah dalam melakukan proses transaksi tentu dengan memanfaatkan teknologi yang ada.

Bank sebagai pengelola dana nasabah tentu berhati-hati dalam menjaga keamanan dana nasabah yang ada didalam rekening masing-masing terutama dana nasabah yang menggunakan aplikasi mobile banking. Sehingga BSM tentu memberikan jaminan keamanan kepada nasabah yang sudah menggunakan mobile bangkingdalam melakukan sebuah transaksi yang dimana dengan memasukkan dana dalam aplikasi mobile banking dengan limit maksimalRp. 100.000.000.000:00. Sehingga BSM bisa mengontrol dana nasabah secara berkala.

Dan apabila terjadi pembobolan pada rekening nasabah oleh orang-orang yang tidak bertanggung jawab maka dana tidak semua bisa hilang akan tetapi sebagian saja, karena BSM mempunyai sistem seperti itu. Sehingga dana nasabah yang tersimpan akan

\footnotetext{
14 Andi Muhammad Amrin, Wawancara, Palu 06 November 2019.
}

mendapat jaminan keamanan dari pihak BSM.

Nasabah menggunakan layanan aktifitas transaksi keuangannya tentu harus berhati-hati agar tidak menjadi korban penipuan dari orang-orang yang tidak bertanggung jawab. Kewaspadaan sebelum dan sesudah melakukan transaksi keuanganan perlu ditingkatkan sebagai langkah antisipasi agar nasabah pengguna mobile banking tidak menjadi korban kejahatan. Sesuai dengan hasil wawancara dapat pemaparan atau penjelasan dari bapak Andi Muhammad Amrin yang mengatakan bahwa:

"Dalam sebuah teknologi seperti aplikasi mobile banking dan ada sebuah kegagalan dalam bertransaksi dan kegagalnya oleh sistem maka pihak bank akan menjamin dana nasabah itu kembali. Contohnya aplikasi mobile banking dalam proses transaksi atau jaringan down maka otomatis saldo sudah terdebet atau hilang. Kalau memang kesalahan oleh sistem maka pihak bank akan mengembalikan dana tersebut kepada nasabah. Nah disitu akan menggunakan dua model yaitu: Apakah secara sistem langsung akan dikembalikan apakah akan menunggu ketentuan bank yang biasanya berjarak 10 samapai 14 hari. Akan tetapi transaksinya karena kesalahan nasabah maka secara otomatis bank tidak bisa mengembalikan dana tersebut". ${ }^{15}$

Berikut beberapa langkah antisipasi yang dilakukan oleh nasabah bank syariah

\footnotetext{
15 Andi Muhammad Amrin, Wawancara, Palu 06 November 2019.
} 
dalam menggunakan aplikasi mobile banking di antaranya yaitu:

a. Merahasiakan informasi penting yang berkaitan dengan identitas nasabah seperti User ID, Passwor dan nomor PIN kepada orang lain termasuk petugas bank. Dalam melakukan vertifikasi, petugas bank tidak pernah meminta nomor PIN kepada nassabah.

b. Melakukan perubahan password nomor PIN secara berkala.

c. Tidak menggunakan password dan nomor PIN dengan angka-angka yang mudah ditebak.

d. Tidak mencatat User ID,Password dan pin di kertas, memori HP atau media lainnya yang memungkinkan orang lain mengetahuinya.

e. Tidak menggunakan Fasilitas mobile phone di HP yang digunakan bersama orang lain.

Masih banyak pemakai tidak menyadari pentingnya dan manfaat khususnya pengguna password sehingga secara gampang mereka memberikan User IDdan passworkepada rekannya tanpa mengetahui dampak apabila mereka memberikan data pribadi yang berakibat fatal. Sistem informasi yang baik dan merekam semua kegiatan pemakai, misalnya sistem akan merekam siapa yang melakukan perubahan terhadap data / informasi dan kapan. Dengan meningkatnya proses transaksi secara onlinedan real time dan terkoneksi jaringan internasional, transaksi akan terlaksana hanya dalam hitungan beberapa detik dengan tidak melibatkan manusia. Transaksi semacam ini apabila terjadi kesalahan tidak dapat langsung diperbaiki atau akan menyita waktu dan upaya untuk memperbaikinya.

Antisipasi dan pencegahan dengan tindakan keamanan yang ketat akan memberikan garansi atau integritas, kelanjutan, dan kerahasiaan transaksi yang terjadi. Tindakan pencegahan tambahan harus diimplementasikan agar dapat mendeteksi dan melaporkan kesalahan yang terjadi sehinnga kejanggalan dapat dikoreksi secepat mungkin. Contohnya seperti saat pemindahan dana melalui ATM atau Mobile Banking.

Dengan seiring majunya teknologi yang ada pada saat ini maka perkembangan mobile banking sampai saat ini dari tahun ke tahun mempunyai perkembangan seperti adanya tambahan fitur-fitur baik sifatnya betul-betul transaksi bank maupun transaksi non bank, seperti bisa secara mandiri membuka fom rekening lewat website, sehingga bisa di bank di perlihatkan model senpasi di coustumer service untuk menunggu tidak terlalu lama yang artinya bisa membuka dengan sendiri. Fitur mobile banking sudah menyediakan tarik tunai tanpa menggunakan ATM, pengguna tinggal 
membuka fitur setelah mendapat kode boking lalu mendatangi ATM BSM disitu bisa tarik tunai tanpa ATM maksimal Rp.500.000:00 disitu akan muncul perintah masukkan no telephone atau kode boking sehinnga uangnya akan keluar.

Upaya yang dilakukan oleh BSM untuk meningkatkan kualitas layanan mobile banking seperti hasil wawancara bapak Andi Muhammad Amrin memaparkan bahwa:

"Yang namanya bank menyadari diri bahwa kekuatan bisnisnya adalah layanan, karena bisnis BSM adalah layanan maka senantiasa mengamati apa kebutuhan nasabah terkait dengan transaksi pada bank. Konsep bertransaksi sekarang ini cendrung non tunai, jadi harapan dari Bank Indonesia (BI) sebagai legulator maupun Otoritas Jasa Keungan (OJK) maupun BSM sendiri sedapat mungkin transaksi itu non tunai. Cara supaya transaksi itu tidak tunai maka otomatis nasabah mempunyai rekening bank termasuk pedagang, toko-toko dan suplayer harus memilimki rekening bank. Sebagai perantara adalah mobile banki $n g$. BSM juga bekerja sama dengan beberapa perusahaan seperti telkomsel, M3, PLN dan lain-lain maka BSM membuat satu fitur pembelian token listrik, pulsa telephone pakai mobile banking dengan catatan membuka rekening di BSM supaya transaksinya berjalan, nah itu semua yang menjadi perhatian BSM"16

Tujuan BSM mengembangkan fitur tambahan adalah untuk membantu regulasi pihak pemerintah melalui Bank Indonesia (BI) untuk mengurangi transaksi tunai

\footnotetext{
${ }^{16}$ Andi Muhammad Amrin, Wawancara, Palu 08 November 2019.
}

dengan harapan lebih aman maka secara otomatis tidak merepotkan karena tidak perlu membawa uang secara tunai dan lebih-lebih dijamin yang menerima uang itu adalah uang asli karena misalkan dibayar tunai bisa saja terselip uang palsu satu lembar, duua lembar bahkan sampai sepuluh lembar, berarti secara otomatis akan rugi dan juga lebih mudah karena tidak perlu kemana-mana cukup saling komunikasi maka transaksi akan selesai sehingga suplayer tinggal kirim barang. Adapun metode yang dilakukan BSM untuk menarik minat para nasabah untuk menggunakan aplikasi mobile banking adalah dengan cara sosialisasi, lewat iklaniklan bahkan kerjasama dengan toko-toko, perusahaan dan pihak-pihak bisnis supaya mempermudah untuk bertransaksi secara online.

Produk layanan transaksi online akan dikatan efektif bukan hanya diketahui melalui informan dari pihak dalam (intern) yakni pihak bank akan tetapi produk ini dikatan efektif apabila diketahui melalui informan luar (ekstern) yakni nasabah. Jadi ketika didapat informasi dari kedua atau lebih dari informan, lebih-lebih dari pihak ekstern atau bisa juga disebut pengguna mobile banking yang sudah mengaplikasikan produk layanan mandiri syariah mobile melalui aplikasi mobile banking maka secara otomatis akan didapat titik jelas efektif atau tidak dari layanan mobile banking itu sendiri 
Berikut ini hasil pemaparan atau penjelasan penulis melalui wawancara dengan pengguna mobile banking atau nasabah di PT Bank Syariah Mandiri Palu selaku informan mengenai efektif atau tidaknya produk layanan mandiri syariah mobile melalui aplikasi mobile banking di PT Bank Syariah Mandiri Palu. Adapun hasil wawancara penulis dengan Riska yang mengatakan bahwa:

"Layanan mandiri syariah mobile yang saya gunakan saat ini melalui aplikasi mobile banking memberikan kemudahan secara online dalam melakukan transaksi yang di mana kemudahan yang kami maksud disini adalah tidak perlu mengunjungi kantor BSM, kami cukup membuka fitur-fitur yang sudah ada di apliaksi mobile banking misalnya isi pulsa, token listrik, bayar tagihan dan lain sebgainya tentu sudah bisa melakukan transaksi melalui telephone dengan menggunakan jaringan seluler, kecuali transaksi tarik tunai yang kami tidak bisa lakukan melalui aplikasi mobile banking ini. Akan tetapi kelemahan yang saya rasakan dalam menggunakan aplikasi mobile bangking ini ketika jaringan eror karena sifat aplikasi mobile bangking ini tergantung pada jaringan, apabila kondisi jaringan normal maka proses transaksi akan berjalan dengan lancar namun begitu juga sebaliknya apabila jaringan tidak normal maka proses transaksi pun akan tidak normal.Menurut kami pribadi selaku pengguna aplikasi mobile banking ini kayak ATM berjalan karena fitur-fitur yang ada didalamnya sebagian besar kayak fitur yang ada di kantor BSM." 17

\subsection{Produk Layanan Transaksi Online}

\section{Menurut Perspektif Ekonomi Syariah}

Dalam produk layanan transaksi online penulis akan mengkaji prinsip-prinsip yang

\footnotetext{
${ }^{17}$ Riska, Nasabah Mobile Bankinsg,

Wawancara di kantor BSM, pada 08 November 2019.
}

di pakai BSM terkait produk layanan transaksi online.

Adapun prinsip-prinsip sebagai berikut:

1. Prinsip Kejujuran.

Kejujuran merupakan tonggak dalam kehidupan masyarakat yang beradab. Setiap orang hendaknya bersikap jujur karena kejujuran dapat mendatangkan ketentraman hati. Faktor yang menyebabkan manusia tidak dapat berlaku jujur seperti iri hati, lingkungan, sosial ekonomi, ingin populer maupun faktor-faktor lainnya. Prinsip kejujuran yang diterapkan oleh PT BSM melalui aplikasi mobile banking pada produk layanan transaksi online tentu menjadi faktor dasar bagi nasabah terhadap loyalitas menggunakan mobile banking. Kejujuran bersifat universal artinya tidak ada niatan lain dari pihak instansi bank BSM terhadap pihak nasabah atau pengguna mobile bankingseperti unsur penipuan melainkan dengan tujuan maslahah mursalah. Prinsip jujur tentu harus di tanamkan di setiap instansi baik dari lembaga keuangan maupun dari sumber daya manusia, terutama pada BSM prinsip kejujuran sudah ada, untuk menjaga popularitas kesyariahannya.

\section{Prinsip Transparansi.}

Tranparansi atau keterbukaan dapat berarti semua kebijakan atau keputusan dan informasi yang berkaitan oleh perusahaan atau instansi oleh para pemangku 
kepentingan di instansi tersebut. Kalaupun ada informasi yang tidak boleh diketahui oleh publik, maka harus ada kriteria yang jelas untuk informasi tersebut. Tranparansi atau keterbukaan juga bisa berarti informasi yang cukup berkaitan dengan kinerja BSM tersedia dan disajikan dalam bentuk atau media yang mudah dipahami pemangku kepentingan atau nasabah pada BSM.

BSM merupakan salah satu instansi yang menerapkan prinsip transparansi untuk menjaga loyalitas dan kepercayaan nasabah dengan menerapkan etika bisnis sebagai 3. aspek mendasar bagi terwujudnya tujuan BSM. Etika bisnis yang baik dalam menerapkan prinsip transparansi mensyaratkan adanya keterbukaan, keterlibatan, dan kemudahan akses bagai nasabah demi menaikkan nilai BSM. Caracara yang dilakukan oleh BSM dalam kegiatan bisnis secara adil sesuai dengan hukum yang berlaku, yang aturannya disetujui atau disepakati oleh seluruh nabah ada di BSM.

Kesuksesan BSM sebagian besar ditentukan kepercayaan nasabah karena tanpa ada kepercayaan dari nasabah maka kinerja dan populeritas BSM tidak akan maju dan berkembang seperti yang kita lihat seperti saat sekarang ini. Prinsip transparansi yang ditandai dengan tersedianya informasi tepat waktu, relevan, dan akurat bagi BSM merupakan salah satu syarat disiplin yang berfungsi secara efektif dan efesien. Jadi implementasi transparansi informasi sehubungan dengan produk layanan mandiri syariah mobile yaitu penyampaian keterangan atau penerangan / pemberitahuan yang mengandung nilai, makna, dan pesan baik fakta maupun penjelasannya yang dapat dilihat, didengar, dan dibaca yang disajikan dengan perkembangan teknologi informasi dan komunikasi secara elektronik atau non elektronik mengenai karakteristik produk layanan mandiri syariah mobile.

\section{Prinsip (ta'awwun)}

Dalam konteks sosial ekonomi, ajaran Islam bersifat dinamis serta keberpihakaanya pada keadilan sosial yang bersifat mutlak. Hal ini karena ketidakadilan bisa merusak tatanan sosial srta bertentangan dengan moralitas. Dalam perspektif ekonomi syariah untuk mewujudkan struktur sosial motivasinya harus didasarkan pada moral yang benar. Pandangan Islam manusia mempunyai kedudukan yang sama di hadapan Allah swt, oleh karena tidak seorangpun yang berhak memperbudak sesamanya sehingga dapat mendorong manusia dengan sukarela melakukan tindakan sosial yang bermanfaat.

Pada prinsip ini BSM juga menerapkankannya dengan tujuan untuk membantu saudara-saudara yang kurang mampu atau golongan ekonomi menengah ke bawah yang tentu membutuhkan uluran 
tangan baik bersifat perorangan atau dari sebuah instansi atau lembaga seperti BSM. Produk layanan transaksi online yang dikembangkan oleh BSM pada aplikasi mobile banking mempunyai fitur zakat infaq, melalui fitur inilah BSM menyalurkan pendapatan lebih kepada para pihak yang membutuhkan dengan tujuan tolong menolong (ta'awwun).

Prinsip (ta'awwun) yang dikembangkan oleh BSM merupakan ciri khas kesyarihaannya yang menjadi sudut pandang nasabah yang bermitra, sehingga dengan prinsip tersebut BSM menjadi salah satu lembaga keuangan yang pada saat ini yang mengembangkan prinsip tolong menolong (ta'awwun) melalui jaringan pada aplikasi mobile banking.

\section{Prinsip Keadilan}

Prinsip keadilan merupakan salah satu prinsip yang esensinya menempatkan sesuatu hanya pada tempatnya dan memberikan sesuatu hanya pada yang berhak serta memperlakukan sesuatu sesuai dengan posisinya. Implementasi keadilan dalam dunia usah atau bisnis berupa aturan muamalah yang melarang adanya unsur sebagai berikut:

a. Riba (unsur bunga dalam segala bentuk dan jenisnya, baik riba nasiah maupun fadhl).

b. Kezaliman (unsur yang merugikan diri sendiri dan orang lain) c. Masyir (unsur judi dan sifat spekulatif)

d. Gharar (unsur ketidakjelasan) s

e. Haram (unsur haram baik dalam barang maupun jasa serta aktivitas operasional yang terkait.

Dalam prinsip keadialan BSM tidak mengkatagorikan prinsip ini yang dipakai dalam produk layanantransaksi online, karena prinsip keadilan ditujukan pada produk seperti: mudharabah, murabahahm, musyarakah dan produk lainya. Alasan BSM tidak mengkatagorikan prinsip ini adalah konteksnya yang berbeda tempat, sebab pada transaksi online aplikasi mobile banking tidak melakukan transaksi yang bersifat menanamkan porsi dana yang akan di bagi hasilkan.

5. Prinsip Kemaslahatan (maslaha)

Prinsip kemaslahatan esensinya merupakan segala bentuk kebaikan dan manfaat yang berdimensi duniawi dan ukhrawi, meterial dan spritual, serta individual dan kolektif. Kemaslahatan yang diakui harus memenuhi dua unsur yakni kepatuhan syariah (halal) serta bermanfaat dan membawa kebaikan (thayib) dalam semua aspek secara keseluruhan yang tidak menimbulkan kemudharatan.

Transaksi syariah yang dianggap bermaslahat harus memenuhi secara keseluruhan unsur-unsur yang menjadi tujuan ketetapan syariah (maqasid syariah) yaitu berupa pemeliharaan terhadap akidah, 
keimanan dan ketaqwaan,intelektual, keturunan, jiwa, keselamatan dan harta benda..

Prinsip kemaslahatan ini juga ada pada BSM dilihat dari beberapa produk-produk dan jasa-jasa yang dikembangkan karena sebagian besar bersifat kemaslahatan bagi pemerintah, nasabah yang bermitra dan tidak kalah penting bagi masyarakat banyak. Nah prinsip kemaslahatan ini di rasakan oleh para nasabah BSM khususnya dan masyarakat umumnya melalui beberapa aplikasi atau fitur yang sudah dikembangkan oleh BSM itu sendiri. Contohnya: pada produk layanan transaksi online yang menggunakan aplikasi mobile banking, sebagian besar fitur sudah menggunakan online atau jaringan yang tentu bersifat kemaslahatan tanpa harus pergi ke tempat bisnis atau bisa dibilang mempermudah dan mempercepat sekaligus menyelesaikan urusan secara efektif. Maka disinilah kita lihat prinsip kemaslahatan ada pada produk layanan mandiri syariah mobile yang menggunakan apalikasi mobile banking.

6. Prinsip Keseimbangan

Prinsip keseimbangan tentu diterapkan pada BSM sebab esensinya meliputi keseimbangan aspek material dan spiritual, aspek privat dan publik, sektor keuangan dan riil, bisnis dan sosial dan aspek pemanfaatan. Dari esensi diatas produk layanan mandiri syariah mobile dalam melakukkan transaksi tidak menekankan pada maksimalisasi keuntungan BSM semata, akan tetapi pada semua pihak yang dapat merasakan adanya suatu kegiatan ekonomi.

7. Prinsip Universalisme

Prinsip universalime ini tentu akan diterapkan oleh BSM karena esensi dari prinsip ini adalah dapat dilakukan semua pihak tanpa harus membedakan suku, agama, ras dan golongan. Produk layanan mandiri syariah mobile merupakan salah satu produk yang menyediakan fitur-fitur secara online, Nah ketika BSM akan melihat pihak secara tertentu misalnya pada agama saja tentu yang terlibat disitu adalah agama Islam saja. Rasulullah saw. Mengajarkan pada umat manusia untuk rahmatan lil alamin. Jadi kalau melihat konteks tersebut BSM sebagai lembaga keuangan syariah tentu akan menerapkan produk-produknya untuk siapa saja dan dimana saja tanpa membedakan dengan mengembangkan produknya lewat online yang biasa kita dengar yakni: aplikasi mobile banking.

Prinsip-prinsip diatas merupakan prinsip yang dipakai oleh BSM dalam menjaankan bisnisnya melalui produk layanan transaksi online dengan menggunakan aplikasi mobile banking. Masih banyak aplikasi yang digunakan oleh BSM sesuai konteks produk yang di dikembangkan dan semua prinsip-prinsip ekonomi syariah di pakai, akan tetapi 
prinsip-prinsip tersebut akan di bagi sesuai dengan konteks produk yang di jalankan oleh BSM itu sendiri.

Berikut hasil pemaparan atau penjelasan dari pimpinan cabang BSM mengenai produk layanan transaksi online. Adapun hasil wawancara dengan bapak Andi Muhammad Amrin selaku informan yang mengatakan bahwa:

"Pada mobile banking prinsip keadilan dalam konteks tidak ada karena prinsip keadilan tidak digunakan pada transaksi tersebut, konteks keadilan digunakan pada transaksi bagi hasil (Mudahrabah), (Murabahah) dan (Musyrakah). Dalam konteks keadilan penabung atau nasabah mendapatkan keuntungan sesuai dengan porsi, maka dalam konteks ini prinsip keadilan berlaku. Prinsip kejujuran bersifat universal jadi transaksi dalam bentuk apapun tidak ada niatan lain-lain kecuali transaksi dengan apa adanya sesuai dengan hukum ekonomi syariah. Prinsip tolong menolong (ta'awwun) ada pada ujung aktivitas BSM, dalam produk layanan mandiri syariah mobile banking, meyediakan fitur-fitur seperti zakat maka secara otomatis nasabah akan memanfaatkannya dan masyarakat atau kelompok lain ikut juga merasakannya, disitu berperan prinsip tolong menolong (ta'awwun) yang mendatangkan suatu kebaikan, jadi prinsip itu terpenuhi tetapi prinsipprinsip ini di suatu transaksi belum tentu ada tetapi prinsip-prinsip ini secara institusi ada.

Prinsip-prinsip diatas tentu berperan penting untuk menjaga proses transaksi secara online bagi pengguna mobile banking dan bagi masyarakat umumnya. Karena tanpa prinsip-prinsip ekonomi syariah dalam melakukan sebuah usaha atau bisnis maka secara otomatis tidak ada perbedaa dengan lembaga keuangan konvensional, sebab yang membedakan antara lembaga keuangan syariah dengan lembaga konvensional adalah prinsip-prinsip yang berlaku dalam menjalan atau mengembangkan usaha terkait di bidang keuangan dan jasa. Dengan adanya prinsipprinsip ekonomi syariah maka akan muncul sebuah etika bisnis yang baik dan benar sesuai dengan tuntunan syaraq yang menghasilkan kemaslahatan bagi para pelaku bisnis atau pengusaha dan umumnya untuk umat manusia di muka bumi ini,.

\section{KESIMPULAN DAN SARAN}

Berdasarkan uraian tentang pokok permsalahan yang diteliti oleh penulis diakhir uaraian ini penulis menyimpulkan sebagai berikut :

Produk layanan mandiri syariah mobile banking merupakan produk layanan yang diterapkan di PT. Bank Syariah Mandiri yang di respon baik oleh nasabah untuk menunjang kegiatan ekonomi dalam proses bertransaksi secara online. Dalam penerapan layanan transaksi online pada aplikasi mobile banking memberikan kemudahan dalam bertransaksi kepada nasabah atau pengguna mobile banking tanpa mengunjungi mesin ATM cukup membuka fitur-fitur yang sudah disediakan dalam aplikasi mobile bankingmaka secara otomatis sudah bisa melakukan transaksi kecuali dalam proses 
tarik tunai dan setor tunai nasabah harus mengunjungi langsung kantor PT. Bank Syariah Mandiri atau mesin ATM.

Produk layanan transaksi online menurut perspektif ekonomi syariah adalah produk yang mengembangkan transaksi secara onlinedengan menggunakan aplikasi mobile banking untuk para nasabah yang sudah membuka rekening di PT Bank Syariah Mandiri. Layanan transaksi online di lengkapi dengan fitur-fitur yang sudah ada, dengan seiring perkembangan teknologi dan informasi tentu transaksi akan semakin canggih bahkan sebagian besar transaksi sudah menggunakan online. Pada produk layanan transaksi online tentu harus menggunakan prinsip-prinsip ekonomi syariah yang bertujuan untuk mengetahui sejauh mana praktik-praktik yang dikembangkan di PT Bank Syariah Mandiri terkait transaksi online yang menggunakan aplikasi mobile banking. Prinsip-prinsip ekonomi syariah ini sangat mendukung dalam peningkatan loyalitas nasabah dalam menggunakan aplikasi mobile banking dalam melakukan transaksi secara online.

\section{DAFTAR PUSTAKA}

Fajar, Riza Yulista , 2009, "Ribadan BungaBank dalam Pandangan Muhammad

Syafi'iAntonio", Yogyakarta: Fakultas Syari'ah UIN Sunan Kalijaga,
Karim. Adiwarman, A, 2017, Bank Islam Analisis Fiqih dan Keuangan, Depok: PT Raja Grafindo Persada.

Ramadhan. Reza, 2016, "Persepsi Kemudahan Penggunaan, Kredibiliitas, dan Persepsi Harga Pada Niat Nasabah Menggunakan Layanan Mobile Banking di Bank Syariah Mandiri Surabaya”, Surabaya: Fakultas Ekonomi dan Bisnis Islam, Universitas Air Langga,

Irianto, Mohammad,2014,Prosedur Audit OperasionalBank:AuditTerapanBerbas isResiko, Bandung: Ikhlas Media,

Tira Nur Fitria, BisnisJualBeli Online DalamHukum Islam Dan Negara, vol. 03 No. 01. Maret 2017.

MaryantoSupriyono, BukuPintarPerbankan, Yogyakarta:2011

Irianto, Mohammad,2014,Prosedur Audit OperasionalBank:AuditTerapanBerbas isResiko, Bandung: Ikhlas Media,

Kelebihan dan Kekurangan Internet Banking dan Sms Banking, diaksesdari http;//www.paketwisatatour. net 2015 pada tanggal 13 Maret 2019.

Novita Putri Wulandari, AnalisisFaktorFaktorPenggunaan Mobile Banking di Bandung, Bisnis dan Iptek Vol.10, No.2, Oktober 2017, 139.

Soemitro. Warkum,2004,Perbankan Islam dan Lembaga-Lembaga Terkait (Takaful dan Pasar ModalSyriah) di Indonesia ,Jakarta: PT Raja GrafindoPersada,

Antonio dan Perwataatmadja,Soemitra,Bank Syariah dariTeoriKePraktik, Jakarta: GemaInsani Press,

DawamRhardjo, ,1999, Islam dan TranformasiSosialEkonomi, Jakarta: LSAF,

Muhammd, 2004Etika BisnisIslami, Yogyakarta: UPP AMP YKPN,

Nurdin, N. (2016). The Roles of Information Technology in Islamic Bank Knowledge Management: A study of Two Syariah Banks in Palu. Hunafa: Jurnal Studia Islamika, 13(2), 181217. doi: 
https://doi.org/10.24239/jsi.v13i2.44

4.181-217

Nurdin, N. (2019). Knowledge Integration Strategy in Islamic Banks. In A. Helena \& S. Bernardete (Eds.), The Role of Knowledge Transfer in Open Innovation (pp. 118-138). Hershey, PA, USA: IGI Global.

Soemitra, Andri,2010, Bank dan Lembaga Keuangan Syariah, Jakarta: Kencana,

Kementrian Agama Ri, 2012, Al-Quran dan Terjemahannya, Semarang: PT Toha Putra,

Sofyan, Syakir, PerkembanganPerbankan Syariah DI Indonesia,(Bilancia, Vol. No.2, Juli - Desember 2016

Muhammad, Sistem dan ProsedurOperasional Bank Syariah, (Yogyakarta: UII Press. 2005), 91

Sudarso, Heri,2003,Bank dan Lembaga Keuangan Syariah Deskripsi dan ilustrasi, Yogyakarta: Ekonisia-FE UII.

Agustina, Arvica, 2015 "EfektivitasPembinaanKemandirianSa ntriMelalui Program Kewirausahaan

\section{Dan}

ImplikasinyaTerhadapKarakterKerjaK erasPondokPesantrenAswajaLintangS ongoPiyungan Bantul"Skripsi Yogyakarta: FakultasIlmuTarbiyah dan Keguruan, Universitas Islam Negeri SunanKalijaga Yogyakarta,

M. Nazir, 2003, MetodePenelitian Jakarta: Ghalia Indonesia,

Basrowi dan Suwandi,2008, MemahamiPenelitianKualitatif, Jakarta: RinekaCipta,

Bank Syariah Mandiri, Annual Report, di akses 22 oktober 2019.

Ismail DaengNurung, Wawancara Bank Syariah MandiriPropinsi Sulawesi Tengah

Riska, Nasabah Mobile Bankinsg, Wawancara di kantor BSM, pada 08 November 2019. 